\title{
In-row Preplant Manure Composting Reduces Weed Populations
}

\author{
Barakat Abu-Irmaileh ${ }^{1}$ \\ Department of Plant Protection, University of Jordan
}

\author{
Azmi Abu-Rayyan \\ Department of Horticulture and Crop Science, University of Jordan
}

Additional index words. environmental pollution, weed control, cow manure, sheep manure, poultry manure, olive pomace, organic farming

\begin{abstract}
Fresh manure is normally broadcasted on the soil surface in vegetable growing areas of Jordan as a source of nutrients and organic matter. However, it can be an environmental pollutant and may lead to the outbreak of many health-related pests, especially houseflies. Field experiments were conducted in two locations to study the effect of in-row composting of four different fresh manures and olive pomace on preplant weed control in vegetables. In the first experiment, main treatments were as follows. 1) Organic materials were applied preplant and then the soil was covered with black polyethylene (BPE) sheets for 6 weeks (M). 2) Treatments were the same as in (M) but the soil surface was covered by BPE mulch for the whole growing season (MP). 3) There was soil incorporation of organic materials preplant, but the soil surface was unmulched during the 6-week period and weeds were controlled chemically later in the season (MC). 4) For the control (C), fresh organic materials were soil incorporated manually at time of planting. Each main treatment included four subtreatments. Each subtreatment received a different source of organic material: cow, poultry, or sheep manure or olive pomace. In the second experiment, the rates of poultry manure $\left(0,5\right.$, and $\left.10 \mathrm{~kg} \cdot \mathrm{m}^{-2}\right)$ comprised the main treatments. Each treatment included four subtreatments in which the manure was soil-incorporated then subplots were covered by BPE sheets for either $0,2,4$, or 6 weeks. The composting process in the main treatments $M$ and MP raised soil temperatures significantly at a $15-\mathrm{cm}$ depth above soils without manure amendments. Soil temperatures were higher, especially with poultry manure, athough not significantly different in all cases. Composting poultry manure was more effective in reducing weed dry weights compared with other organic materials.
\end{abstract}

Improved use of animal manures has a central role in efforts to decrease the undesirable environmental impacts of farming (Brown, 1995; University of California, 2001). Efficient use of nutrients in organic amendments can reduce the need for applied mineral fertilizers. Composting of manure can also reduce weed seed viability (Bahman and Lesoing, 1999) and reduce other pests, such as plant diseases and flies (Brown, 1995). Many attempts have been made to adapt organic waste treatment technologies for managing animal manures. The treatments are normally designed to solve odor problems, recover nutrients and energy from manure, increase the fertilizer value, reduce the volume, or decrease the pollution potential to allow safe discharge of the manure in the environment (Hammill and Murphy, 1999). Manure management practices are strictly regulated and enforced in the developed countries to minimize pollution problems (Hammill and Murphy, 1999). But management of surplus manure in the animal production sector is far from satisfactory in developing

Received for publication 21 Jan. 2003. Accepted for publication 6 Oct. 2003. This research was funded by the University of Jordan- Deanship of Scientific Research. Authors extend their gratitude to M. Suwwan, I. Nazer, and L. Banna for their assistance in writing up the manuscript, and to O. Kafawin for checking the statistical analysis.

${ }^{1}$ Faculty of Agriculture, University of Jordan; email barakat@.ju.edu.jo. countries. Manure is normally sold at low prices to farmers who spread raw manure on the soil surface at rates ranging from 50 to $100 \mathrm{t} \cdot \mathrm{ha}^{-1}$. Manure is considered a source of nutrients and organic matter for improving soil fertility and soil texture. However, this practice creates an environmental hazard, as manure is a favorable medium for the multiplication and propagation of various microorganisms and insects, including houseflies (Musca domestica L.) (Crosskey and Lane, 1993). In addition, manure can intensify weed problems. Collected raw manure from grazing animal barnyards (goat and sheep) is normally contaminated with seeds of various plant species; are normally allowed to graze crop remains and weeds after harvest (personal observation). Therefore, raw manure could increase the weed seed bank on receiving fields. Thus, disposal of manures, without any further composting treatment, is a major environmental pollutant in agro-ecosystems.

Weed infestations are one of the most limiting factors in irrigated vegetable production. Weed infestations can result in serious yield losses compared to other constraints in crop production (Abu-Irmaileh and El Kady, 1997; Azrag, 1985). Weeds can drastically reduce yields (Abu-Irmaileh, 1991b) and may lead to crop failure in noncompetitive vegetable crops such as onions, Allium cepa L., and carrots, Daucus carota L. ssp. sativus (Hoffm.)Thell. Chemical weed control is a difficult task in as these animals, and to a lesser extent cattle, small farming systems, especially where intercropping is practiced, or when two or three different crops are sequentially rotated per year. Residual herbicides limit crop rotation and herbicide drift could be risky in small farms where many crops are grown in close proximity, if not inter-cropped (Ross and Lembi, 1999). Farmers in most developing countries remove weeds by manual hoeing (Parker and Abu-Irmaileh, 1987). In these countries chemical weed control is typically unaffordable, especially if more than one herbicide is required and if market economics limit profits. Nonchemical weed control practices are favored by many small farmers in warm regions if the systems are cost effective. An example is soil solarization with black plastic mulch that has been widely adopted by Jordanian farmers in the Jordan Valley for the control of weeds and other pests (Abu-Irmaileh and Saghir, 1994). However, such practice is limited to the hottest months of the year.

Aerobic manure composting converts manure into compost at a rate that depends on many factors including the availability of moisture and oxygen. Heat generation can elevate temperatures to $\approx 65^{\circ} \mathrm{C}$ under a controlled aerobic composting process (Hammill and Murphy, 1999). Such high temperatures could be effective in controlling pest propagules and weed seeds under moist conditions (Al-Raddad, 1979; Brown, 1995; Grooshevoy, 1939; Linke et al., 1991; Silva et al., 1996; Stapleton and De Vay, 1982; University of California, 2001). Temperatures from composting are normally highest in moist manure. In watered beef lot manure, temperatures can reach $62.8^{\circ} \mathrm{C}$ and effectively kill weed seeds within 1 week of composting (Bahman and Lesoing, 1999). It is also known that with increasing soil temperatures less time is required to inhibit soilborne pests. For example, it has been found that a temperature of $37^{\circ} \mathrm{C}$ is lethal for many mesophilic fungi if it is maintained in the soil for four weeks (Pullman et al., 1981), whereas at $47^{\circ} \mathrm{C}$, a 1- to 6-h exposure will inhibit egg hatching of many nematodes (Lamberti and Greco, 1991).

Fly larvae do not survive composting at such high temperatures (Brown, 1995). Heat generated during decomposition is sufficiently high enough to warm propagating media when manure is placed underneath the propagating frames (Maynard et al., 1999; McGroarty, 1998).

The objective of this study was to determine the effect of composting manure applied in planting rows, on weed populations in onions and eggplant.

\section{Materials and Methods}

Effect of in-row composting on weed control. Field experiments were conducted during the 2000-01 growing season at two locations in the Jordan valley; the Agricultural Research Station-University Farm (longitude $35^{\circ} 35.7^{\prime} \mathrm{E}$, latitude $32^{\circ} 05^{\prime} \mathrm{N}$ ), and at a private farm in Kreimeh, $20 \mathrm{~km}$ north of the university farm. Soil in both locations is ostochreptic calciorthid. In-row composting was conducted by thor- 
oughly mixing organic materials with the soil to a depth of $30 \mathrm{~cm}$ in the planting rows. Mixing was done manually. The soil surface was either covered by black polyethylene (BPE) sheets or left uncovered during the 6 -week period prior to planting. Composting was conducted for 6 weeks, starting on 14 Sept. 2000, until 30 Oct. 2000, at the university farm; and from 4 Nov. 2000 until 17 Dec. 2000, at Kraimeh. Short day onion seedlings, Allium cepa $\mathrm{L}$. 'Texas Early Grano 502', were planted in rows 30 $\mathrm{cm}$ apart and at $20-\mathrm{cm}$ distances in each row, immediately after the end of the composting period. All plots were drip irrigated to field capacity once per week during the composting period and stopped during periods of rainfall. Drip lines were $50 \mathrm{~cm}$ apart, with emitters 40 $\mathrm{cm}$ apart in-line. Fertilizers were not added. Onion brown rot caused by the fungus Botrytis spp. was controlled as needed by the application of a combination of cymoxanil and mancozeb (Remaltin, cymoxanil $4 \%$ and mancozeb 46\%,) at an a.i. rate of $2.5 \mathrm{~g} \cdot \mathrm{L}^{-1}$ followed by procemidone at an a.i. rate of $1.0 \mathrm{~g} \cdot \mathrm{L}^{-1} 2$ weeks later. The experiment included four main treatments, $10 \times 2 \mathrm{~m}$ in size: 1) composting under BPE cover, $60 \mu$ thick for 6 weeks before planting $(\mathrm{M}) ; 2$ ) composting as in $\mathrm{M}$, then BPE mulch was used for the whole growing season (MP); 3) composting for 6 weeks without BPE but controlling emerging weeds with a postemergent application of cycloxydim applied at 0.2 $\mathrm{kg} \cdot \mathrm{ha}^{-1}$ a.i. to emerging weeds, followed 1 week later by oxadiazon applied at $1.25 \mathrm{~kg} \cdot \mathrm{ha}^{-1}$ a.i. as a preemergent to obtain broad spectrum weed control (MC); and, 4) a control treatment in which fresh organic materials were soil-incorporated at the time of planting $(\mathrm{C})$. Weeds were allowed to grow in $\mathrm{C}$ for almost the whole growing season. Subplots in the main treatments received either cow, sheep, poultry manure or olive pomace and were thoroughly mixed in the soil at rate of $10 \mathrm{~kg} \cdot \mathrm{m}^{-2}$. The subplot size was $2 \times 1.5 \mathrm{~m}$ with $0.5 \mathrm{~m}$ alleys on all sides. The experiment was arranged in a split plot design with four replications.

To monitor the effect of fresh manure and olive pomace composting on soil temperature, soil thermometers (bench checked for accuracy to $\pm 0.1^{\circ} \mathrm{C}$ ) were placed at a $15 \mathrm{~cm}$ depth in each subplot of the main treatments M and MP and in an untreated, mulched soil as a check. Temperatures were recorded twice daily at 8 : $00 \mathrm{Am}$ and at 3:00 PM. The average of these two soil temperatures were used to calculate a daily mean. From these, weekly means were calculated during the composting period. Beginning in February 2001, weed species and weed dry weights were recorded from the middle $1 \mathrm{~m}^{2}$ of each subplot during their flowering stages. Green bunch onions were harvested at Kreimeh during the middle of March to determine crop yield. Onions were harvested at the University Farm in early June 2001, to determine the crop yield as dry bulb onions. Soil analysis performed at the University of Jordan determined the soil to be a sandy loam with $80 \%$ sand, $12.5 \%$ silt and $7.5 \%$ clay, with $<1 \%$ organic matter. Soil pH ranged from 7.5 to 7.9.

Effect of rate and periodicity of poultry manure composting on weed control efficacy.
Since composting with poultry manure gave the best weed control in the first experiment, a split-plot field experiment with four replications was conducted at the university farm to study the efficacy of weed control and vegetable yields using different rates of applied poultry manure, composted for varying lengths of time. The main treatment was the duration of composting, and subplots were the rates of application. Fresh poultry manure was thoroughly mixed with the soil in the planting rows at rates of 0,5 , or $10 \mathrm{~kg} \cdot \mathrm{m}^{-2}$ to a depth of $30 \mathrm{~cm}$, then covered with BPE for $0,2,4$ ,or 6 weeks followed by planting. The 6 -week treatment was initiated on 17 Mar. 2001; the four week treatment on $1 \mathrm{Apr}$. 2001; the two week treatment on Apr. 15, 2001, and the zero week treatment were mixed in-row at planting time. The subplot size was $1.5 \times 3 \mathrm{~m}$. At the end of the composting period, the BPE cover was removed and eggplant, Solanum melongena L. 'Classic', was planted in early May 2001. The plots were drip-irrigated the same as in the previous treatment with the exception that irrigations were scheduled every $5 \mathrm{~d}$, which is a normal irrigation cycle for farmers at this time of year. Fertilizers were not added and no other pest control was required. Data on weed dry weights and weed species present were recorded in late June. Five eggplants were taken at flowering stage from the middle of each subplot to obtain their fresh weight.

Four plots were established outside the experimental area as untreated and unamended checks to determine soil temperatures during each composting period. The soil of each subplot was thoroughly mixed with cow, olive pomace, poultry or sheep manure at 10 $\mathrm{kg} \cdot \mathrm{m}^{-2}$, irrigated, then covered with BPE. Soil thermometers were inserted in the plots at 15 $\mathrm{cm}$ depths, and temperatures were recorded as previously described.

Analysis of variance was conducted with the SAS program, version 7 , for split-plot arrangement, and the interactive means were

Table 1. Separate effects of the various treatments on total weed dry weights and onion yield at Kreimeh and University farm (10 km south of Dayr Alla).

\begin{tabular}{|c|c|c|c|c|}
\hline \multirow[b]{3}{*}{ Treatment } & \multirow{2}{*}{\multicolumn{2}{|c|}{ Total weed dry wt $\left(\mathrm{g} \cdot \mathrm{m}^{-2}\right)$}} & \multicolumn{2}{|c|}{ Onion yield $\left(\mathrm{t} \cdot \mathrm{ha}^{-1}\right)$} \\
\hline & & & \multicolumn{2}{|c|}{ University farm } \\
\hline & University farm & Kreimah & (mature bulbs) & (green bunch) \\
\hline \multicolumn{5}{|l|}{ Main plot treatment ${ }^{2}$} \\
\hline $\mathrm{M}$ & $8.4 c^{y}$ & $5.17 \mathrm{bc}$ & $55.3 \mathrm{a}$ & $52.62 \mathrm{~b}$ \\
\hline MP & $16.4 \mathrm{c}$ & $1.0 \mathrm{c}$ & $47.7 \mathrm{~b}$ & $67.04 \mathrm{a}$ \\
\hline $\mathrm{MC}$ & $45.2 \mathrm{~b}$ & $51.67 \mathrm{~b}$ & $42.4 \mathrm{~b}$ & $25.58 \mathrm{c}$ \\
\hline $\mathrm{C}$ & $185.9 \mathrm{a}$ & $154.64 \mathrm{a}$ & $4.8 \mathrm{c}$ & $8.39 \mathrm{~d}$ \\
\hline $\mathrm{LSD}_{005}$ & 19.01 & 50.36 & 7.57 & 6.65 \\
\hline \multicolumn{5}{|l|}{ Subplot treatment } \\
\hline Cow & $75.9 \mathrm{ab}$ & $82.6 \mathrm{a}$ & $35.5 \mathrm{~b}$ & $41.66 \mathrm{~b}$ \\
\hline Olive pomace & $57.3 \mathrm{~b}$ & $34.6 \mathrm{ab}$ & $42.8 \mathrm{ab}$ & $22.50 \mathrm{c}$ \\
\hline Poultry & $34.7 \mathrm{c}$ & $17.1 \mathrm{~b}$ & $44.3 \mathrm{a}$ & $50.28 \mathrm{a}$ \\
\hline Sheep & $88.1 \mathrm{a}$ & $78.1 \mathrm{a}$ & $27.6 \mathrm{c}$ & $39.18 \mathrm{~b}$ \\
\hline $\mathrm{LSD}_{0.05}$ & 19.01 & 50.36 & 7.57 & 6.65 \\
\hline \multicolumn{5}{|l|}{ Significance } \\
\hline Main treatment & $* * *$ & $* * *$ & $* * *$ & $* * *$ \\
\hline Subplot treatment & $* * *$ & $* *$ & $* * *$ & $* * *$ \\
\hline Main $\times$ subplot & $* * *$ & NS & $* *$ & NS \\
\hline
\end{tabular}

${ }^{\mathrm{z}} \mathrm{M}=$ in-row manure composting under $\mathrm{BPE}$ cover, $\mathrm{MP}=$ in-row manure composting under BPE cover + $\mathrm{BPE}$ mulch for the whole growing season, $\mathrm{MC}=$ in-row manure composting without $\mathrm{BPE}$ cover + chemical weed control treatment, $\mathrm{C}=$ manure and olive pomace was mixed with the soil at time of planting.

${ }^{y}$ Means within columns with the same letters are not significantly different at $P \leq 0.05$, according to least square means by GLM procedures (SAS institute,1998). separated by least squared means according to procedure (Statistical Analysis System, 1998). $\mathrm{LSD}_{0.05}$ values are shown on tables where appropriate.

\section{Results and Discussion}

Effect of in-row composting on weed control. All treatments with preplant in-row osting of organic materials (M, MP, or than the control treatment, $\mathrm{C}$, at both locations (Table 1). Plots with composted manure in the planting row under BPE cover for 6 weeks planting (M and MP) resulted in the When the organic materials were composted without BPE cover during the 6-week period (MC), weeds emerged and they were controlled with herbicides. The applied post emergent achieve complete cont ing in higher weed dry weights than in the M or MP plots. Weed species appearing in MC plots after herbicide applications were Cyperus esculentus L. and Cynodon dactylon (L.) Pers. Weed dry weights in the MC treatment, at Kreimah, also tended to be (Table1). The dominant weed species in plots at Kreimah were Melilotus indica (L.)All., Polygonum aviculare L., Lolium perenne L., and Sorghum halepense (L.)Pers. These weeds seemed to tolerate the applied herbicides, tion from other vegetation, overtopped onion plants and caused significant reductions in the green bunch onion yields compared to those in treatments M or MP (Table 1). In addition to the previous species, Portulaca oleraceae L., Sisymbrium irio L., and Malva nicaeensis All. appeared in the control treatment plots. The dominant weed species in the control plots at the university farm included Chenopodium album L., C. murale L., Amaranthus retroflexus 
L., Sonchus oleraceous L., Malva nicaeensis, and Cynodon dactylon.

Composting under BPE cover during the 6-week period before planting, in the main treatments $\mathrm{M}$ and MP, effectively reduced weed growth throughout the growing season. This may be because the BPE cover during the composting process retained more volatile compounds evolving from the soil, such as ammonia and ammonium, which enhanced detrimental effects on weed growth. Ammonia is known to be a product of manure composting and could reduce plant growth at high enough concentrations. It has been reported to have a scorching effect on plant foliage (Simpson, 1986), and it is used as a defoliant in many crops (Foster et al., 1995). There were no statistical differences in weed dry weights between the main treatments M and MP. Mulching with BPE after composting, (MP) enhanced onion growth early in the season and resulted in higher green bunch yields at Kreimah (Table 1).

Manure types varied in their effects on weed dry weights. Poultry manure was the most effective in reducing weed dry weights at the university farm, but was comparable to olive pomace at Kreimah (Table 1). Manures in the control treatment $\mathrm{C}$ resulted in the highest weed dry weights at the university farm, but the subplots which received cow or sheep manure resulted in higher weed dry weights than poultry manure or olive pomace (Table 2 ). This result was expected as sheep, and to a lesser extent cows, are normally allowed to graze either in rangeland or in farms after crop harvest, while poultry are normally fed in confinement (personal observation). Onion yields were significantly improved by the inrow composting of organic materials in any of the main treatments; M, MP, or MC. But onion yields in subplots receiving sheep manure was the lowest in the MC treatment probably because the herbicides used did not control all weeds present.

Overall, preplant composting of organic materials improved crop dry weights and enhanced weed control. Even though not always statistically different from other sources of organic material, there seemed to be a trend for in-row composted poultry manure to give lower weed dry weights and a general improvement of onion yields.(Table 1). This could be that poultry manure is higher in nitrogen and phosphorous content (Ensminger, 1970; Maynard et al., 1999; Simpson, 1986), in addition to its greater efficacy in controlling weeds (Tables 1, 2, and 5).

The yield of green bunch onions in the olive pomace treatment was significantly lower than the poultry manure treatment at Kreimah, except in control plots (Table 1). Even though both treatments were normally less contaminated with weed seeds, the olive pomace treatment had a higher weed infestation, especially Melilotus indica, which overtopped onion plants and was probably responsible for the lower yields. Onion bulb yields obtained from olive pomace at the university farm were similar to that of poultry manure (Table 1 ). Onion bulb yields from poultry plots were higher than that from olive pomace in the MC treatment, probably due to a lower weed infestation (Table 2). Weed infestations in the subplots of olive pomace and poultry manure in treatments $\mathrm{M}, \mathrm{MP}$, and $\mathrm{C}$ were the lowest.

It is well established that mulching with BPE can raise soil temperatures (Hopen, 1965; Lai, 1974), but in-row composting of organic materials resulted in higher soil temperature than BPE in this experiment during the summer months (Table 3 ). Comparing soil temperatures at $15 \mathrm{~cm}$ depths, daily means were always higher in plots where manures or olive pomace were applied than those in mulched soils without manure or olive pomace (Table 3 ). The highest weekly mean soil temperatures

were in plots which received poultry and sheep manure, followed by olive pomace or cow manure (Table 4). Composting of poultry manure raised the weekly mean from 3.2 to $10.1^{\circ} \mathrm{C}$ over that in soil without manure (Table 4). The highest weekly mean soil temperature was $47.7^{\circ} \mathrm{C}$ in plots, which received poultry manure during the last week of the composting period 17 Mar. to 30 Apr. (Table 4). Such a rise in temperature could also be obtained by soil solarization using BPE during the hottest months of the year (Abu-Irmaileh, 1991b). This rise in soil temperature at the 15 -cm depth was associated with effective weed control. But these temperatures were only obtained

Table 2. Interactive effects of the various treatments on total weed dry weight and onion bulb yield at the university farm.

\begin{tabular}{|c|c|c|c|c|}
\hline Treatment $^{2}$ & $\begin{array}{c}\text { Cow } \\
\text { manure }\end{array}$ & $\begin{array}{c}\text { Olive } \\
\text { pomace }\end{array}$ & $\begin{array}{l}\text { Poultry } \\
\text { manure }\end{array}$ & $\begin{array}{l}\text { Sheep } \\
\text { manure }\end{array}$ \\
\hline & \multicolumn{4}{|c|}{ Total weed dry wt $\left(\mathrm{g} \cdot \mathrm{m}^{-2}\right)$} \\
\hline M & $7.0 \mathrm{f}^{\mathrm{y}}$ & $10.3 \mathrm{ef}$ & $0.1 \mathrm{f}$ & $16.5 \mathrm{ef}$ \\
\hline MP & 19.5 ef & $12.8 \mathrm{ef}$ & $8.4 \mathrm{f}$ & $25.0 \mathrm{ef}$ \\
\hline $\mathrm{MC}$ & $39.4 \mathrm{def}$ & $46.9 \mathrm{de}$ & $2.7 \mathrm{ef}$ & $67.6 \mathrm{~cd}$ \\
\hline \multirow[t]{2}{*}{$\mathrm{C}$} & $238.0 \mathrm{a}$ & $159.1 \mathrm{~b}$ & $103.3 \mathrm{c}$ & $243.0 \mathrm{a}$ \\
\hline & \multicolumn{4}{|c|}{ Onion bulb yield $\left(\mathrm{t} \cdot \mathrm{ha}^{-1}\right)$} \\
\hline M & $52.8 \mathrm{ab}$ & $62.2 \mathrm{ab}$ & $52.3 \mathrm{ab}$ & $54.0 \mathrm{ab}$ \\
\hline MP & $40.8 \mathrm{~b}$ & $60.1 \mathrm{ab}$ & $48.8 \mathrm{ab}$ & $41.0 \mathrm{~b}$ \\
\hline $\mathrm{MC}$ & $47.2 \mathrm{~b}$ & $44.3 \mathrm{~b}$ & $62.8 \mathrm{a}$ & $15.3 \mathrm{c}$ \\
\hline $\mathrm{C}$ & $1.0 \mathrm{~cd}$ & $4.7 \mathrm{~cd}$ & $13.6 \mathrm{~cd}$ & $0.1 \mathrm{~d}$ \\
\hline
\end{tabular}

-row manure composting under BPE cover, MP = in-row manure composting under BPE cover + $\mathrm{BPE}$ mulch for the whole growing season, $\mathrm{MC}=$ in-row manure composting without $\mathrm{BPE}$ cover + chemical weed control treatment, $\mathrm{C}=$ manure and olive pomace was mixed with the soil at time of planting.

${ }^{y}$ Means with the same letters, within either parameters (total weed dry weight or onion bulb yield), are not significantly different at $P \leq 0.05$, according to least square means by GLM procedures (SAS institute, 1998).

Table 3. Temperature means \pm SE at $15 \mathrm{~cm}$ depth taken daily at 8:00 AM and 3:00 PM under black plastic during the 6-week composting period in Kreimeh and the university farm locations. Check is composed of mulched plots without organic material.

\begin{tabular}{|c|c|c|c|}
\hline \multirow[b]{3}{*}{ Treatment } & \multicolumn{3}{|c|}{ Soil temp $\left({ }^{\circ} \mathrm{C}\right)$} \\
\hline & \multicolumn{2}{|c|}{ University farm } & \multirow{2}{*}{$\begin{array}{c}\text { Kreimeh } \\
\text { Onion } \\
(1 \text { Nov. to } 30 \text { Dec. })\end{array}$} \\
\hline & $\begin{array}{c}\text { Onion } \\
\text { (15 Sept. to } 30 \text { Oct.) }\end{array}$ & $\begin{array}{c}\text { Eggplant } \\
\text { (17 Mar. to } 30 \text { Apr.) }\end{array}$ & \\
\hline Cow & $32.3 \pm 0.7 \mathrm{~b}^{\mathrm{z}}$ & $33.8 \pm 0.5 b$ & $23.6 \pm 0.6 \mathrm{~b}$ \\
\hline Olive pomace & $32.3 \pm 0.7 b$ & $33.1 \pm 0.5 b$ & $24.5 \pm 0.6 b$ \\
\hline Poultry & $33.8 \pm 0.8 \mathrm{~b}$ & $36.3 \pm 0.6 \mathrm{c}$ & $25.9 \pm 0.6 \mathrm{c}$ \\
\hline Sheep & $33.1 \pm 0.7 b$ & $34.5 \pm 0.5 b$ & $24.2 \pm 0.6 \mathrm{~b}$ \\
\hline Check & $28.0 \pm 0.5 \mathrm{a}$ & $31.5 \pm 0.4 \mathrm{a}$ & $20.7 \pm 0.5 \mathrm{a}$ \\
\hline
\end{tabular}

${ }^{2}$ Means within columns with the same letters are not significantly different.

Table 4. Weekly means of soil temperature ( $\pm \mathrm{SE})$ at $15 \mathrm{~cm}$ depth taken at 3:00 PM during the 6-week period of manure composting. Organic material was not mixed into soil in the check plots.

\begin{tabular}{|c|c|c|c|c|c|c|}
\hline \multirow[b]{2}{*}{ Treatment } & \multicolumn{6}{|c|}{ Weekly means of soil temp $\left({ }^{\circ} \mathrm{C}\right)^{z}$} \\
\hline & $1^{\mathrm{st}}$ & $2^{\text {nd }}$ & $3^{\text {rd }}$ & $4^{\text {th }}$ & $5^{\text {th }}$ & $6^{\text {th }}$ \\
\hline \multicolumn{7}{|c|}{ Kreimeh (1 Nov. to $30 \mathrm{Dec}$ ) } \\
\hline Cow & $34.1 \pm 0.6 \mathrm{~b}$ & $32.7 \pm 0.4 b$ & $27.1 \pm 0.6 \mathrm{~b}$ & $25.0 \pm 0.2 \mathrm{~b}$ & $23.7 \pm 0.4 b$ & $22.6 \pm 0.2 b$ \\
\hline Olive pomace & $34.6 \pm 0.2 b$ & $33.4 \pm 0.3 b$ & $30.0 \pm 0.4 \mathrm{c}$ & $27.9 \pm 0.5 \mathrm{~cd}$ & $25.3 \pm 0.6 \mathrm{~b}$ & $22.6 \pm 0.4 b$ \\
\hline Poultry & $35.7 \pm 0.4 \mathrm{c}$ & $35.0 \pm 0.4 \mathrm{c}$ & $32.0 \pm 0.5 \mathrm{~d}$ & $28.4 \pm 0.4 \mathrm{~d}$ & $26.7 \pm 0.4 \mathrm{c}$ & $25.7 \pm 0.3 \mathrm{c}$ \\
\hline Sheep & $34.7 \pm 0.4 \mathrm{~b}$ & $33.3 \pm 0.5 b$ & $27.9 \pm 0.7 \mathrm{~b}$ & $26.9 \pm 0.5 \mathrm{c}$ & $24.3 \pm 0.5 b$ & $22.4 \pm 0.2 b$ \\
\hline Check* & $26.9 \pm 0.4 \mathrm{a}$ & $27.0 \pm 0.3 \mathrm{a}$ & $24.7 \pm 0.4 \mathrm{a}$ & $22.4 \pm 0.3 \mathrm{a}$ & $19.9 \pm 0.3 \mathrm{a}$ & $19.0 \pm 0.4 \mathrm{a}$ \\
\hline \multicolumn{7}{|c|}{ University farm-onion (15 Sept. to 30 Oct.) } \\
\hline Cow & $40.9 \pm 0.7 b$ & $39.4 \pm 0.7 \mathrm{~b}$ & $39.8 \pm 0.3 b$ & $37.4 \pm 0.4 b$ & $33.5 \pm 0.5 b$ & $27.9 \pm 0.6 b$ \\
\hline Olive pomace & $41.5 \pm 0.6 b$ & $40.2 \pm 0.7 b$ & $39.2 \pm 0.3 b$ & $36.1 \pm 0.5 b$ & $33.9 \pm 0.5 b$ & $26.5 \pm 0.8 b$ \\
\hline Poultry & $44.3 \pm 0.7 \mathrm{c}$ & $41.7 \pm 0.9 b$ & $41.6 \pm 0.4 \mathrm{c}$ & $37.6 \pm 0.9 b$ & $35.7 \pm 0.3 \mathrm{c}$ & $28.4 \pm 0.7 b$ \\
\hline Sheep & $41.6 \pm 0.5 b$ & $40.1 \pm 0.8 b$ & $40.3 \pm 0.4 b$ & $36.7 \pm 0.5 b$ & $34.4 \pm 0.4 b$ & $28.6 \pm 0.4 b$ \\
\hline Check & $36.7 \pm 0.2 \mathrm{a}$ & $34.0 \pm 0.7 \mathrm{a}$ & $34.9 \pm 0.5 \mathrm{a}$ & $31.2 \pm 0.5 \mathrm{a}$ & $29.2 \pm 0.7 \mathrm{a}$ & $24.6 \pm 0.7 \mathrm{a}$ \\
\hline \multicolumn{7}{|c|}{ University farm-eggplant (17 Mar. to 30 Apr.) } \\
\hline Cow & $33.9 \pm 0.2 \mathrm{a}$ & $36.1 \pm 0.8 \mathrm{~b}$ & $36.9 \pm 0.9 b$ & $37.2 \pm 0.9 b$ & $40.9 \pm 0.5 \mathrm{c}$ & $42.3 \pm 1.0 \mathrm{~b}$ \\
\hline Olive Pomace & $34.8 \pm 0.3 b$ & $35.3 \pm 0.6 a b$ & $36.3 \pm 0.9 \mathrm{ab}$ & $36.9 \pm 0.4 b$ & $39.4 \pm 0.5 b$ & $42.8 \pm 0.6 b$ \\
\hline Poultry & $36.4 \pm 0.7 \mathrm{c}$ & $38.9 \pm 0.8 \mathrm{c}$ & $39.0 \pm 1.0 \mathrm{c}$ & $41.1 \pm 1.1 \mathrm{~d}$ & $44.1 \pm 0.7 \mathrm{~d}$ & $47.7 \pm 0.6 \mathrm{c}$ \\
\hline Sheep & $34.9 \pm 0.6 b$ & $36.5 \pm 1.0 \mathrm{~b}$ & $37.4 \pm 1.0 \mathrm{bc}$ & $38.6 \pm 0.9 \mathrm{c}$ & $40.8 \pm 0.4 \mathrm{c}$ & $43.5 \pm 0.4 b$ \\
\hline Check & $33.2 \pm 0.8 \mathrm{a}$ & $34.3 \pm 0.8 \mathrm{a}$ & $34.8 \pm 1.1 \mathrm{a}$ & $32.5 \pm 1.0 \mathrm{a}$ & $35.6 \pm 0.4 \mathrm{a}$ & $37.6 \pm 0.4 \mathrm{a}$ \\
\hline
\end{tabular}

${ }^{2}$ Means within columns with the same letters in each location are not significantly different. 
Table 5. Separate effects of composting period and rate of application of poultry manure on dry weight means of eggplants and weeds.

\begin{tabular}{|c|c|c|}
\hline \multirow[b]{2}{*}{ Treatment } & \multicolumn{2}{|c|}{ Dry $w^{2}$} \\
\hline & Eggplant (g/plant) & Weeds $\left(\mathrm{g} \cdot \mathrm{m}^{-2}\right)$ \\
\hline \multicolumn{3}{|c|}{ Composting period (weeks) } \\
\hline 0 & $13.56 \mathrm{~b}$ & $468.0 \mathrm{a}$ \\
\hline 2 & $15.23 \mathrm{ab}$ & $424.6 \mathrm{ab}$ \\
\hline 4 & $18.67 \mathrm{ab}$ & $397.6 \mathrm{bc}$ \\
\hline 6 & $23.16 \mathrm{a}$ & $342.0 \mathrm{c}$ \\
\hline $\mathrm{LSD}_{005}$ & 9.32 & 64.72 \\
\hline \multicolumn{3}{|c|}{ Rate of application $\left(\mathrm{kg} \cdot \mathrm{m}^{-2}\right)$} \\
\hline 0 & $12.85 \mathrm{~b}$ & $594.0 \mathrm{a}$ \\
\hline 5 & $16.87 \mathrm{ab}$ & $308.3 \mathrm{~b}$ \\
\hline 10 & $23.24 \mathrm{a}$ & $321.9 \mathrm{~b}$ \\
\hline $\mathrm{LSD}_{00}$ & 8.07 & 56.05 \\
\hline \multicolumn{3}{|l|}{ Significant levels } \\
\hline Rate of application & $*$ & **** \\
\hline Composting period & NS & $* *$ \\
\hline Period $\times$ rate & NS & NS \\
\hline
\end{tabular}

${ }^{2}$ Means within columns with the same letters are not significantly different at $P \leq 0.05$, according to least square means by GLM procedures (SAS institute,1998).

Ns,***,****Nonsignificant or significant at $P \leq 0.05,0.01$, or 0.001 , respectively.

for 1 week during the in-row composting period. In-row composting treatments were effective in controlling weeds even when soil temperatures were less than that obtained by soil solarization. The enhanced efficacy in weed control during the composting process could be partly due to the rise in temperature. However, weed seeds can be killed during composting even though lethal temperatures are not reached (Bahman and Lesoing, 1999). The efficacy of the composting process for controlling soilborne living propagules is not necessarily dependent on simply raising soil temperatures. For instance, imbibed weed seeds have been reported to be killed faster than nonimbibed weed seeds at typically sublethal soil temperatures when under mulch (Standifer et al., 1984). The rise in soil temperature obtained as a result of in-row composting in the soil may be less than the rise obtained during soil solarization with clear polyethylene sheets during summer months (Abu-Irmaileh, 1991a). Some weed species and other soilborne pest propagules may not be controlled effectively if plastic mulch is applied during the winter months when solar energy levels are lower. When fresh manures are mixed in-row during the cooler time of the year (15 Sept. to 30 Oct.) at rates used in this research the heat generated from decomposition does not bring about soil temperatures high enough for effective weed control (Tables 3 and 4). Apparently, some weed species present required soil temperatures higher than this to be killed (Egley, 1983). However, weed dry weights were apparently much less than that of the control treatment, $\mathrm{C}$ (Tables 1, 2, and 5). Soil temperatures taken at 3:00 $\mathrm{PM}$ in plots where poultry manure was composted was raised to $44.3^{\circ} \mathrm{C}$ at a 15 $\mathrm{cm}$ depth during the period of 15 Sept. to 30 Oct. (Table 4). Soil temperatures in the upper soil layer, near the surface could be 5 to $6^{\circ} \mathrm{C}$ higher toward afternoon hours (Arcidiacono et al., 1997) possibly reaching $50{ }^{\circ} \mathrm{C}$. These temperatures could provide effective control of heat sensitive winter weed species. Seeds of many weed species lose their viability within 1 week of soil solarization with transparent PE sheets in midsummer (Egley, 1983).
Weed species observed in plots where organic material was composted under PE for 6weeks without any further mulching included Cyperus esculentus, Cynodon dactylon, Prosopis farcta (Banks et Sol) Macbride, Sorghum halepense, Melilotus indica, and Vicia narbonense L. Weed species effectively controlled included Chenopodium murale, C. album, Amaranthus retroflexus, Sonchus oleraceous, Polygonum aviculare, and Sisymbrium irio. Fewer weeds were observed in plots where poultry manure or olive pomace was composted. In addition to a loss in the viability of weed seeds (Bahman and Lesoing, 1999), this result could be due to lower contamination from poultry manure or olive pomace which normally contains fewer weed seeds, and to the higher heat generated during composting, especially in plots receiving poultry manure. It is also probable that ammonia and other nitrogenous compounds released during the decomposition of organic materials (Simpson, 1986) participated in reducing weed seed viability and suppressing subsequent weed growth.

Effect of rate and periodicity of poultry manure composting on weed control efficacy. In-row composting of poultry manure at 10 $\mathrm{kg} \cdot \mathrm{m}^{-2}$ for 6 weeks effectively reduced weed dry weights and improved eggplant dry weights (Table 5). Weed growth was significantly reduced when poultry manure was mixed in the planting row and composted for 4 and 6 weeks. However, the in-row composting process is a preplant treatment and requires that the field be crop free for the whole period of composting. Even though not statistically different, composting poultry manure at either 5 or $10 \mathrm{~kg} \cdot \mathrm{m}^{-2}$ for 4 weeks showed a trend toward higher crop dry weights and brought about significantly lower weed dry weights than $0 \mathrm{~kg} \cdot \mathrm{m}^{-2}$ rate of manure application during this growing season (Table 5). Thus in cases where a crop-free, 6-week period is not feasible, composting for 4 weeks may provide some measure of weed control and increase yields.

Even though data on weed control and on improvement of crop plant growth suggest that higher rates of poultry manure is more effective, this may pose undesirable environmental side effects. Higher application rates combined with heavy irrigation may lead to the emission of nitrogen and carbon into the air, and the leaching of nitrogen to ground and surface water, while the accumulation of heavy metals in the soil may induce levels in crops that exceed human health standards (de Wit et al., 1999).

Covering the soil with BPE mulch during the cooler months, without poultry manure before planting, did not reduce weed dry weights (Table 5). Unlike mulching with BPE during the summer months for the purpose of weed control by soil solarization, (Abu-Irmaileh, 1991a, 1991b), mulching during the composting period between March and April, did not raise soil temperatures high enough to control weeds (Tables 3 and 4).

Temperatures in manure composting lagoons can reach $65^{\circ} \mathrm{C}$ (Silva et al., 1996; University of California, 2001). However our soil temperatures during in-row composting never reached $65^{\circ} \mathrm{C}$. The highest weekly mean of soil temperatures taken at 3:00 PM for cow manure was $42.3^{\circ} \mathrm{C}$, olive pomace $42.8^{\circ} \mathrm{C}$, poultry manure $47.7^{\circ} \mathrm{C}$, and sheep manure $43.5^{\circ} \mathrm{C}$ (Table 4). Although not statistically significant, soil temperatures in poultry manure treatments were consistently higher than in other organic material sources (Table 3). This effect might have contributed to greater control of the dominant weed species, especially during the warmer period (Table 5). The summer weed species that flourish under moist warm conditions include Amaranthus retroflexus, Polypogon monspeliensis (L.)Desf., Portulaca oleraceae, Prosopis farcta, and Tribulus terrestris L.

In conclusion, composting organic material within the planting row was effective in reducing weed populations under certain circumstances. This effect was not due to elevated soil temperatures in all cases, as the warming effect did not raise soil temperatures enough to control weed seeds and other propagules in the soil during the whole composting period. High temperatures were only achieved when composting was done during the warmest part of the seasons which lasted for only 1 week. The composting process could have reduced seed viability of sensitive weeds by the releasing volatile decomposition products. In-row manure composting under some conditions might be an alternative to soil solarization since it does not have to be performed during the hottest month of the year. The farmer can apply this method provided there is a crop-free period from 4 to 6 weeks long. Manure or olive pomace composting not only provided good weed control but it improved the growing conditions and increased crop yield. This process could provide better management of organically cultivated crops and reduce environmental pollution. However, further verification of its environmental impact should be performed in order to make better management decisions regarding the use of these techniques.

\section{Literature Cited}

Abu-Irmaileh, B.E. 1991a. Soil solarization controls broomrape (Orobanche spp.) in host vegetable crops in the Jordan Valley. Weed Technol. 5: 575-581. 
Abu-Irmaileh, B.E. 1991b. Weed control in squash and tomato fields by soil solarization in Jordan Valley. Weed Res. 31:125-133.

Abu-Irmaileh, B.E. and A.R. Saghir. 1994. Components of successful weed management with special reference to vegetable growers in the Near East. FAO Plant Protection Bul. Paper \#30, 683/B. 42(4):191-200.

Abu-Irmaileh, B.E. and A.S. El Kady. 1997. Some factors affecting pest control in Jordan (in Arabic, with English summary). Arab J. Plant Protection 15(1):24-30.

Al-Raddad,A.M. 1979. Soil disinfestations by plastic tarping. MSc thesis. Univ. Jordan, Amman.

Arcidiacono, C., G. Cascone, C.R. Fichera, and D. Gutkowski. 1997. Thermal effects of coextruded black plastic mulches in greenhouse soil, p. 110-120. In: J.J.Stapleton, J.E.Devay, and C.L. Elmore (eds.). 1998. Proc. soil solarization and integrated management of soilborne pests. FAO Plant Prod. Protection paper \#147.

Azrag, S.E. 1985. Future trends in agricultural production within the Arab countries, p. 5-15. In: FAO improved weed management in the Near East. Proc FAO expert consultation on improved weed management in the Near East. FAO plant production and protection paper \#80. Nicosia, Cyprus, 30 Oct. -1 Nov. 1985.

Bahman, E. and G.W. Lesoing. 1999. Viability of weed seeds following manure composting. Tektran, USDA-ARS. Oct. 1999. <http: //www.nal.usda.gov/ttic/tektran/data/000010/ 47/0000104751.html.

Brown, S.J. 1995. Manure composting: A solution to dealing with stricter environment regulations. In: Sustainable farming, resources efficient agricultural production (REAP-Canada) QC. <http://www.eap.mcgill.ca/MagRack/SF/ Winter\%2095\%20E.htm.

Crosskey, R.W. and R.P. Lane. 1993. House-flies, blow-flies and their allies (calyptrate Diptra). chapter 11. p. 403-428. In: R.P. Lane and R.W.
Crosskey (eds.). 1993. Medical insects and arachnids. Chapman and Hall. London.

De Wit, J., H. Van Keulen, H.G. Van der Meer, and A.J. Nell. 1999. Animal manure: Asset or liability. <http://www.fao.org/ag/aga/agap/frg/feedback/ war/w5256t/w5256t05.htm.

Egley, G.H. 1983. Weed seed and seedling reduction by soil solarization with transparent polyethylene sheets. Weed Sci. 31:404-409.

Ensminger, M.E. 1970. The stockman's handbook of animal agriculture, p. 487-489.4th ed. Interstate Printers and Publishers, Inc. Danville, Ill.

Foster, R., E. Knake, R.H. McCarty, and J.J. Mortvedt (eds.). 1995. Farm chemical handbook. Section C, p. 22. Meister Publ. Co., Willoughby. Ohio.

Grooshevoy, S.E. 1939. Disinfestation of seed-bed soil in cold frames by solar energy.A.E. Mikoyan Pan. Soviet Sci. Rese. Inst. Tob. Indian Tob. and Ind.(VITIM), Krasnodar, Publ. 137, p. 51-56. (English summary in Review of Applied Mycology 18:635).

Hammill, E. and M. Murphy. 1999. Alternate methods of manure treatment and utilization. In: Guidelines for management for Prince Edward Island. P.E.I. Dept. Agr. For.-P.E.I. Dept. Technol. Environ. Manitoba, Canada. <http: //www.gov.mb.ca/agriculture/livestock/pork/ swine/bah11s01.html.

Hopen, H.J. 1965. Effects of black and transparent polyethylene mulches on soil temperature, sweet corn growth, and maturity in cool growing season. Proc. Amer. Soc.Hort. Sci.. 86:415-420.

Lai, R. 1974. Soil temperature, soil moisture, and maize yield from mulched and unmatched tropical soils. Plant and Soil 40:129-143.

Lamberti, F. and N. Greco. 1991. Effectiveness of soil solarization for control of plant parasitic nematodes, p. 167-173. In: J.E. De Vay, J.J. Staplelton, and C.L. Elmore (eds.). 1991. Soil solarization. Proc. 1st Intl. Conf. Soil Solarization. Amman, Jordan, 19-25. Feb. 1990. FAO Plant Prod. Protection Paper 109.
Linke, K.H., M.C. Saxena, J.Sauerborn, and H. Masri. 1991. Effect of soil solarization on the yield of food legumes and on pest control, p. 139-154. In: J.E. De Vay, J.J. Staplelton, and C.L. Elmore (eds.). 1991. Soil solarization. Proc. 1st Intl. Conf. Soil Solarization. Amman, Jordan, 19-25. Feb. 1990. FAO Plant Prod. Protection Paper 109.

Maynard, D.N., G.J. Hochmuth (contributor), and J.E. Knott. 1999. Knott's handbook for vegetable growers, p. 581. 4th ed. John Wiley and Sons, London.

McGroarty,M.J. 1998. Using bottom heat topropagate your cuttings. <http://www.freeplants.com.

Parker, R. and B.E. Abu-Irmaileh. 1987. Weed control manual for the Jordan Valley. Univ. Jordan Publ.

Pullman, G.S., J.E. De Vay, and R.H.Garber. 1981. Soil solarization and thermal death:A logarithmic relationship between time and temperature for four soilborne plant pathogens. Phytopathology 71:959-964.

Ross, M.A. and C.A. Lembi. 1999. Applied weed science, p.1-22. 2nd ed. Prentice Hall, N.J.

Silva, J.A., E.L. Woods, W.C. Coleman, J.R Carpenter, and E. Ross. 1996. The use of composted poultry manure as a fertilizer. $<$ http: //www.hawaii.edu/.ansc/Proceed/Aggrowth/ manure.htm

Simpson. K. 1986. Fertilizers and manures. Longman, London. Chapter 8, pp.: 83-108.

Standifer, L.C., P.W. Wilson, and R. Porche-Sorbet. 1984. Effects of solarization on soil weed seed population. Weed Sci. 32:569-573.

Staplelton, J.J. and J.E. De Vay. 1982. Effect of soil solarization on populations of selected soil-borne microorganisms and growth of deciduous fruit tree seedlings. Phytopathology 72:323-326.

Statistical Analysis System (SAS). 1998. Version 7. SAS Inst., Cary, N.C.

University of California. 2001. Building fertile soil. Ctr. Agro-ecology and Sustainable Food. Univ. Calif, Santa Cruz. <http://zzyx.ucsc.edu/casfs/ gardenideas/soilfert.html. 